\title{
Leptostracans (Crustacea: Phyllocarida) from the Ría de Ferrol (Galicia, NW Iberian Peninsula), with description of a new species of Nebalia Leach, 1814
}

\author{
JUAN MOREIRA ${ }^{1}$, GUILLERMO DÍAZ-AGRAS ${ }^{1}$, MARÍA CANDÁS ${ }^{1}$, \\ MARCOS P. SEÑARÍS ${ }^{1}$ and VICTORIANO URGORRI ${ }^{1,2,3}$ \\ ${ }^{1}$ Estación de Bioloxía Mariña da Graña, Universidade de Santiago de Compostela, Casa do Hórreo, Rúa da Ribeira 1, \\ E-15590, A Graña, Ferrol, Spain. E-mail: juan.moreira@usc.es \\ ${ }^{2}$ Departamento de Zooloxía e Antropoloxía Física, Universidade de Santiago de Compostela, Campus Sur, E-15782, \\ Santiago de Compostela, Spain. \\ ${ }^{3}$ Instituto de Acuicultura, Universidade de Santiago de Compostela, Campus Sur, E-15782, Santiago de Compostela, \\ Spain.
}

\begin{abstract}
SUMMARY: Knowledge on taxonomy and ecology of leptostracan crustaceans is still scarce in many parts of the world Sampling in subtidal sediments in the Ria of Ferrol (NW Spain) between 2006 and 2007 yielded several leptostracan specimens belonging to six species. This is, so far, the largest number of leptostracan species reported from a single area. Some specimens belong to an undescribed species of Nebalia Leach, 1814, which is described herein as N. reboredae n. sp. The new species has a rostrum about 2.2 times as long as wide, the antennular scale is slightly more than twice as long as wide, the fourth article of the antennule has one short thick distal spine, the first article of the endopod of the second maxilla is 1.3 times as long as the second one, the exopod of the second maxilla is longer than the first article of the endopod, the posterior dorsal borders of pleonites 5-7 are provided with distally rounded to truncated denticles, and the uropods are as long as pleonite 7 and the anal somite combined. All the species collected are reported, including the number of specimens, sexual condition and substrate type. A key to all known neritic species of the Iberian Peninsula is provided.
\end{abstract}

Keywords: Crustacea, Leptostraca, Nebalia, Sarsinebalia, subtidal, sediment, Ría de Ferrol, Atlantic.

RESUMEN: Leptostráceos (Crustacea: Phyllocarida) de la Ría de Ferrol (Galicia, NO península Ibérica) con LA DESCRIPCIÓN DE UNA NUEVA ESPECIE DE NEBALIA LEACH, I 8 I 4. - El conocimiento sobre la taxonomía y ecología del orden Leptostraca en muchas partes del mundo es todavía fragmentario. El examen de muestras infralitorales recolectadas en la Ría de Ferrol (NO península Ibérica) entre 2006 y 2007 ha revelado la presencia de seis especies de leptostráceos. Hasta la fecha, este es el mayor número de especies encontradas en una única área. Varios de los ejemplares encontrados pertenecen a una especie no descrita del género Nebalia Leach, 1814, que es descrita en el presente trabajo como N. reboredae n. sp. La nueva especie se caracteriza por presentar un rostro 2.2 veces más largo que ancho, una escama antenular algo más de dos veces más larga que ancha, el cuarto segmento de la anténula porta una única espina corta gruesa distal, el primer segmento del endopodio de la segunda maxila es 1.4 veces más largo que el segundo segmento, el exopodio de la segunda maxila es más largo que el primer segmento del endopodio, los dentículos del borde posterior dorsal de los pleonitos 5-7 son distalmente de redondeados a truncados, y los urópodos son tan largos como el pleonito 7 y el somita anal combinados. Se indica para todas las especies encontradas tanto el número de ejemplares como estado sexual y tipo de sustrato. Se incluye una clave para todas las especies de leptostráceos neríticos encontrados en la península Ibérica hasta la fecha.

Palabras clave: Crustacea, Leptostraca, Nebalia, Sarsinebalia, infralitoral, sedimento, Ría de Ferrol, Atlántico. 


\section{INTRODUCTION}

Leptostracans (Crustacea, Phyllocarida) are characterised by the presence of a hinged rostrum, a carapace that covers the thoracic segments, eight pairs of phyllopodus thoracic appendages and seven abdominal segments (Haney and Martin, 2005). The order Leptostraca comprises about 42 known extant species belonging to 10 valid genera (Haney and Martin, 2004). The species concept for this order was revised by Dahl (1985), who proposes new diagnostic characters useful for the identification of species and for revising and describing several taxa (Dahl, 1985, 1990). Consequently, the examination of specimens from collections worldwide by other specialists has resulted in the description of a number of new species of Leptostraca (e.g. Kazmi and Tirmizi, 1989; Escobar-Briones and Villalobos-Hiriart, 1995; Martin et al., 1996; Vetter, 1996d; Walker-Smith, 1998; Olesen, 1999; Haney et al., 2001; Moreira et al., 2003a; Haney and Martin, 2004). Examination of further collections will undoubtedly result in the description of new taxa, thus revealing a greater diversity within the group than was previously thought (Haney and Martin, 2005).

Leptostracans are found in a number of marine habitats, such as hard substrata with algae, seagrasses and sediments (Dahl, 1985), and from the intertidal zone to the hydrothermal vents (Haney and Martin, 2005). Some species achieve large densities in some substrata (Martin et al., 1996; Vetter, 1996c) and in conditions of organic enrichment (MacLeod et al., 2007). Recent work suggests that some leptostracans might be found in significant numbers solely in particular environments. For instance, Vetter (1996c) reported two species of Nebalia from Southern California coexisting in the same area but occurring in different sediments; experimental manipulations also showed that those species search for their own preferred sediment, avoiding that of the other (Vetter, 1996c). Nevertheless, our knowledge on life-history and ecology for most of the known species is scarce at best (but see Rainer and Unsworth, 1991; Modlin, 1996; Vetter, 1996a, 1996b, 1996c; Lee and Morton, 2005) and more data are needed for a better understanding of the order.

An examination of samples from subtidal sediments collected in the Ría de Ferrol (Galicia, NW Spain) during several sampling programmes done between 2006 and 2007 yielded specimens of leptostracans belonging to six species. This is, so far, the largest number of species reported from a single area. Some of these specimens belong to an undescribed species of Nebalia Leach, 1814, which is described herein as $N$. reboredae n. sp. All the species collected in the Ría de Ferrol are reported in this paper, including the number of specimens, sexual condition and type of sediment from which they were collected. A key to all known neritic species of the Iberian Peninsula is provided as well.

\section{MATERIAL AND METHODS}

The Ría de Ferrol is located in NW Galicia (Spain), between $43^{\circ} 27^{\prime}$ and $43^{\circ} 30^{\prime} \mathrm{N}$ and between $08^{\circ} 09^{\prime}$ and $08^{\circ} 21^{\prime} \mathrm{W}$. It is a fully marine environment (salinity: $32-25$ ). It is $15 \mathrm{~km}$ long and comprises an area of $25 \mathrm{~km}^{2}$, with maximum depths of about 35-40 m. Sampling covered most of the subtidal sediments of the ria (from gravel to mud), except those located in the innermost area. Samples were taken between 2006 and 2007 by means of a naturalist's dredge and two van Veen grabs with a

TABLE 1. - Coordinates and physical characteristics of the sampling sites at which leptostracans were found in the Ría de Ferrol. $\mathrm{Q}_{50}$, median grain size; $\mathrm{CO}_{3}=$, carbonate content; TOM, total organic matter content; NDR, naturalist dredge; VV, van Veen grab.

\begin{tabular}{|c|c|c|c|c|c|c|c|c|c|c|}
\hline Sites & $\begin{array}{l}\text { Position } \\
\text { (N) }\end{array}$ & $\begin{array}{l}\text { Position } \\
\text { (W) }\end{array}$ & $\begin{array}{l}\text { Depth } \\
\text { (m) }\end{array}$ & $\begin{array}{c}\text { Gravel } \\
(\%)\end{array}$ & $\begin{array}{c}\text { Sand } \\
(\%)\end{array}$ & $\begin{array}{l}\text { Silt/Clay } \\
(\%)\end{array}$ & Sedimentary type & $\begin{array}{c}\mathrm{CO}_{3}= \\
(\%)\end{array}$ & $\begin{array}{c}\text { TOM } \\
(\%)\end{array}$ & $\begin{array}{l}\text { Sampling } \\
\text { equipment }\end{array}$ \\
\hline AP1 & $43^{\circ} 27.706^{\prime}$ & $8^{\circ} 16.580^{\prime}$ & 12.7 & 42.5 & 51.7 & 5.8 & Very coarse sand & 73.1 & 3.7 & NDR \\
\hline AP2 & $43^{\circ} 27.795^{\prime}$ & $8^{\circ} 16.592^{\prime}$ & 13.5 & 63.7 & 34.1 & 2.2 & Gravel & 82.3 & 0.6 & NDR \\
\hline PE1 & $43^{\circ} 27.033^{\prime}$ & $8^{\circ} 20.385^{\prime}$ & 41.1 & 1.5 & 96.1 & 2.4 & Coarse sand & 83.7 & 1.0 & VV $0.1 \mathrm{~m}^{2}$ \\
\hline PE8 & $43^{\circ} 27.402$ ' & $8^{\circ} 19.350^{\prime}$ & 20.0 & 0.3 & 95.3 & 4.4 & Medium sand & 71.2 & 1.4 & VV $0.1 \mathrm{~m}^{2}$ \\
\hline RP8 & $43^{\circ} 27.577^{\prime}$ & $8^{\circ} 17.938^{\prime}$ & 15.2 & 17.7 & 77.1 & 5.2 & Coarse sand & 38.4 & 2.1 & VV $0.1 \mathrm{~m}^{2}$ \\
\hline NA1 & $43^{\circ} 27.681^{\prime}$ & $8^{\circ} 16.745^{\prime}$ & 14.7 & 9.7 & 85.7 & 4.6 & Coarse sand & 75.8 & 2.6 & VV $0.1 \mathrm{~m}^{2}$ \\
\hline NA9 & $43^{\circ} 27.877^{\prime}$ & $8^{\circ} 16.686^{\prime}$ & 13.8 & 66.3 & 29.6 & 4.1 & Gravel & 88.8 & 4.9 & VV $0.1 \mathrm{~m}^{2}$ \\
\hline MU11 & $43^{\circ} 28.105^{\prime}$ & $8^{\circ} 15.332$ & 20.0 & 64.1 & 32.3 & 3.6 & Gravel & 87.2 & 3.1 & VV $0.1 \mathrm{~m}^{2}$ \\
\hline $\mathrm{SC} 1$ & $43^{\circ} 27.919^{\prime}$ & $8^{\circ} 18.061^{\prime}$ & 6.4 & 0.6 & 96.7 & 2.7 & Medium sand & 46.2 & 1.4 & VV $0.05 \mathrm{~m}^{2}$ \\
\hline CA1 & $43^{\circ} 27.297^{\prime}$ & $8^{\circ} 17.900$ & 4.5 & 2.0 & 95.4 & 2.6 & Fine sand w/ Z. marina & 75.8 & 1.2 & VV $0.05 \mathrm{~m}^{2}$ \\
\hline CA2 & $43^{\circ} 27.271^{\prime}$ & $8^{\circ} 18.118^{\prime}$ & 6.0 & 2.4 & 95.0 & 2.6 & Fine sand $\mathrm{w} / Z$. marina & 46.1 & 1.4 & VV $0.05 \mathrm{~m}^{2}$ \\
\hline
\end{tabular}


TABLE 2. - Comparative table showing collection sites, depth range and sedimentary features for the six known species of leptostracans from the Ría de Ferrol.

\begin{tabular}{|c|c|c|c|c|c|c|c|c|}
\hline Species & Collection sites & Depth (m) & Gravel (\%) & Sand $(\%)$ & Silt/Clay (\%) & Sedimentary type & $\mathrm{CO}_{3}=(\%)$ & TOM (\%) \\
\hline N. kocatasi & $\mathrm{AP} 1, \mathrm{NA} 9, \mathrm{CA} 1, \mathrm{CA} 2$ & $4.5-13.8$ & $2.0-66.3$ & $29.6-95.4$ & $2.6-5.8$ & Gravel to fine sand & $46.1-88.8$ & $1.2-4.9$ \\
\hline N. reboredae & n. sp. & 6.4 & 0.6 & 96.7 & 2.7 & Medium sand & 46.2 & 1.4 \\
\hline N. strausi & AP1, AP2, NA9, RP8 & $12.7-15.2$ & $17.7-66.3$ & $29.6-77.1$ & $2.2-5.8$ & Gravel to coarse sand & $38.4-88.8$ & $0.6-4.9$ \\
\hline N. troncosoi & PE1, PE8, CA1, CA2, SC1 & $4.5-41.1$ & $0.3-2.4$ & $95.0-96.7$ & $2.4-4.4 \quad \mathrm{C}$ & Coarse sand to fine sand & $46.1-83.7$ & $1.0-1.4$ \\
\hline S. cristoboi & AP2, NA1, NA9, PE1, MU11 & $13.5-41.1$ & $1.5-66.3$ & $29.6-96.1$ & $2.2-4.6$ & Gravel to coarse sand & $75.8-88.8$ & $0.6-4.9$ \\
\hline S. urgorrii & AP1, PE8, RP8 & $12.7-20.0$ & $0.3-42.5$ & $51.7-95.3$ & $4.4-5.8$ & $\begin{array}{l}\text { Very coarse sand to } \\
\text { medium sand }\end{array}$ & $38.4-73.1$ & $1.4-3.7$ \\
\hline
\end{tabular}

different sampling surface $\left(0.1 \mathrm{~m}^{2}\right.$ and $\left.0.056 \mathrm{~m}^{2}\right)$. Specimens were fixed in 5\% formaldehyde, rinsed with fresh water and then preserved in $70 \%$ ethanol. Leptostracans were found at 11 subtidal stations at depths of between 4 and $41 \mathrm{~m}$ (Table 1,2). For each sampling site, a sediment sample was taken to determine granulometry, calcium carbonate (\%), and total organic matter (TOM, \%). Sedimentary types were characterised according to Junoy and Viéitez (1989). Calcium carbonate content (\%) was estimated by treating the sample with hydrochloric acid. The total organic matter content (TOM, \%) was estimated from the weight loss on combustion at $450^{\circ} \mathrm{C}$ for 4 hours.

Line drawings of leptostracans were done with the aid of a camera lucida connected to a compound microscope. Drawings of Nebalia reboredae n. sp. were made from the holotype and two dissected adult females. Specimens used for scanning electron microscope (SEM) were dehydrated via a graded ethanol series, prepared by critical-point drying using $\mathrm{CO}_{2}$, coated with gold in a BAL-TEC SCD 004 evaporator, and examined and photographed with a JEOL JSM-6400 scanning electron microscope at the Servicios de Apoio á Investigación, Universidade da Coruña (SAIN), Spain. Measurements were made with an ocular micrometer. Total length (TL) was measured from the articulation between rostrum and carapace to the posterior end of the uropods excluding setation; dorsal carapace length (DCL) was considered as the distance between the articulation of the rostrum and the margin of the posterodorsal cleft; lateral carapace length (LCL) was considered as the distance along the lateral surface between the anteriormost and posteriormost margin; carapace height $(\mathrm{CH})$ was measured between the dorsal and ventral margin; rostrum length (RL) was measured along the midline. Description of specimens followed the model of Dahl (1985) and other recent studies (e.g. Martin et al., 1996; Olesen, 1999; Haney and Martin, 2005). The type series of Nebalia reboredae n. sp. is deposited in the Museo Nacional de Ciencias Naturales, Madrid, Spain (MNCN) and in the Zoological Museum Hamburg, Hamburg, Germany (ZMH).

\section{SYSTEMATICS}

\section{Family Nebalindae Samouelle, 1819 \\ Genus Nebalia Leach, 1814 \\ Nebalia strausi Risso, 1826}

(Fig. 1E)

Nebalia strausi Dahl, 1985: 155, Figs. 63-78; Moreira et al., 2004: 84, Figs. 1-6.

Material examined. 3 ovigerous females, station AP1, 8 August 2006. Ovigerous female, st. AP2, 8 August 2006. 2 subadult males, st. NA9, 13 August 2006. Ovigerous female, st. RP 8, 13 August 2007.

Ecology. Coarse sediments, from gravel to coarse sand, at depths of 12.7-15.2 m.

Distribution. Eastern Atlantic, from the north west coast of France to St. Helena (Dahl, 1985). Western Mediterranean (Dahl, 1985). Eastern Mediterranean (Koçak and Katagan, 2006; Koçak et al., 2007).

\section{Nebalia troncosoi Moreira, Cacabelos and Domínguez, 2003}

(Fig. 1D)

Nebalia troncosoi Moreira et al., 2003a: 341, Figs. 1-8.

Material examined. 3 juveniles, st. PE1, 13 August 2007. Juvenile, st. PE8, 7 September 2006. Adult male, st. CA1, 7 September 2006.

2 specimens (ovigerous female, juvenile), st. CA1, 9 August 2007. 8 spec. (subadult male, 7 juveniles), st. CA2, 9 August 2007. 2 spec. (adult male, juvenile), st. SC1, 9 August 2007. 2 adult males, st. SC1, 19 August 2007. 14 spec. (3 preovigerous females, 2 subadult males, 2 adult males, 7 juveniles), st. SC1, 24 October 2007.

Ecology. Coarse sand to fine sand with mats of Zostera marina (L.), at depths of 4.5-41.1 m.

Distribution. Galicia, NW Iberian Peninsula (Moreira et al., 2003a). 

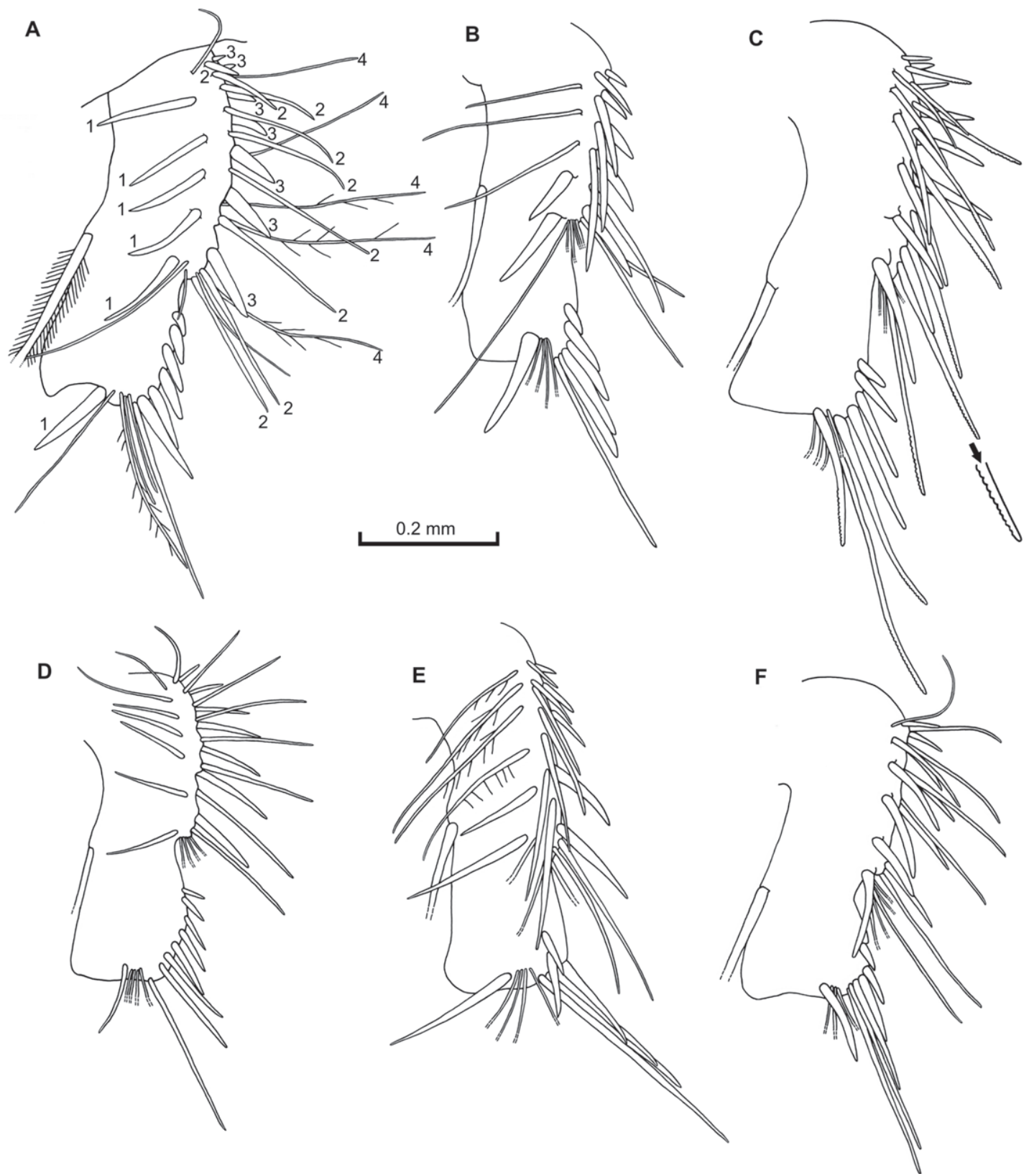

FIG. 1. - Armature of external side and medial border of antennal third article of the leptostracans of the Ría de Ferrol; A, Nebalia reboredae n. sp.; B, Nebalia kocatasi; C, Sarsinebalia cristoboi; D, Nebalia troncosoi; E, Nebalia strausi; F, Sarsinebalia urgorrii. Numbers identify rows of setae (see text for explanations). Setae of row 4 are not illustrated for B-F.

\section{Nebalia kocatasi}

Moreira, Koçak and Katagan, 2007 (Fig. 1B)

Nebalia kocatasi Moreira et al., 2007: 1247, Figs. 2-8.

Material examined. Subadult male, st. AP1, 7 September 2006. Ovigerous female, st. NA9, 13 August 2006. 2 spec. (preovigerous female, juvenile), st. CA1, 9 August 2007. Juvenile, st. CA2, 19 August 2007.

Ecology. Gravel to fine sand with mats of Z. marina, at depths of 4.5-13.8 $\mathrm{m}$.
Distribution. Eastern Mediterranean (Moreira et al., 2007). Galicia.

Nebalia reboredae Moreira and Urgorri n. sp. (Figs. 1A, 2-10)

Material examined. Holotype (MNCN 20.04/7996). Ovigerous female, RL $0.9 \mathrm{~mm}$, DCL $1.8 \mathrm{~mm}$, LCL $2.2 \mathrm{~mm}$, CH $1.5 \mathrm{~mm}$, TL $4.0 \mathrm{~mm}$, st. SC1, 20 August 2007. Type locality: San Cristobo, Ría de Ferrol (Galicia, Spain), 4327.919’N - 8º18.061'W, 6.4 m depth, medium sand. Paratypes: preovigerous female, subadult male (MNCN 20.04/7997), st. SC1, 9 August 2007. Preoviger- 


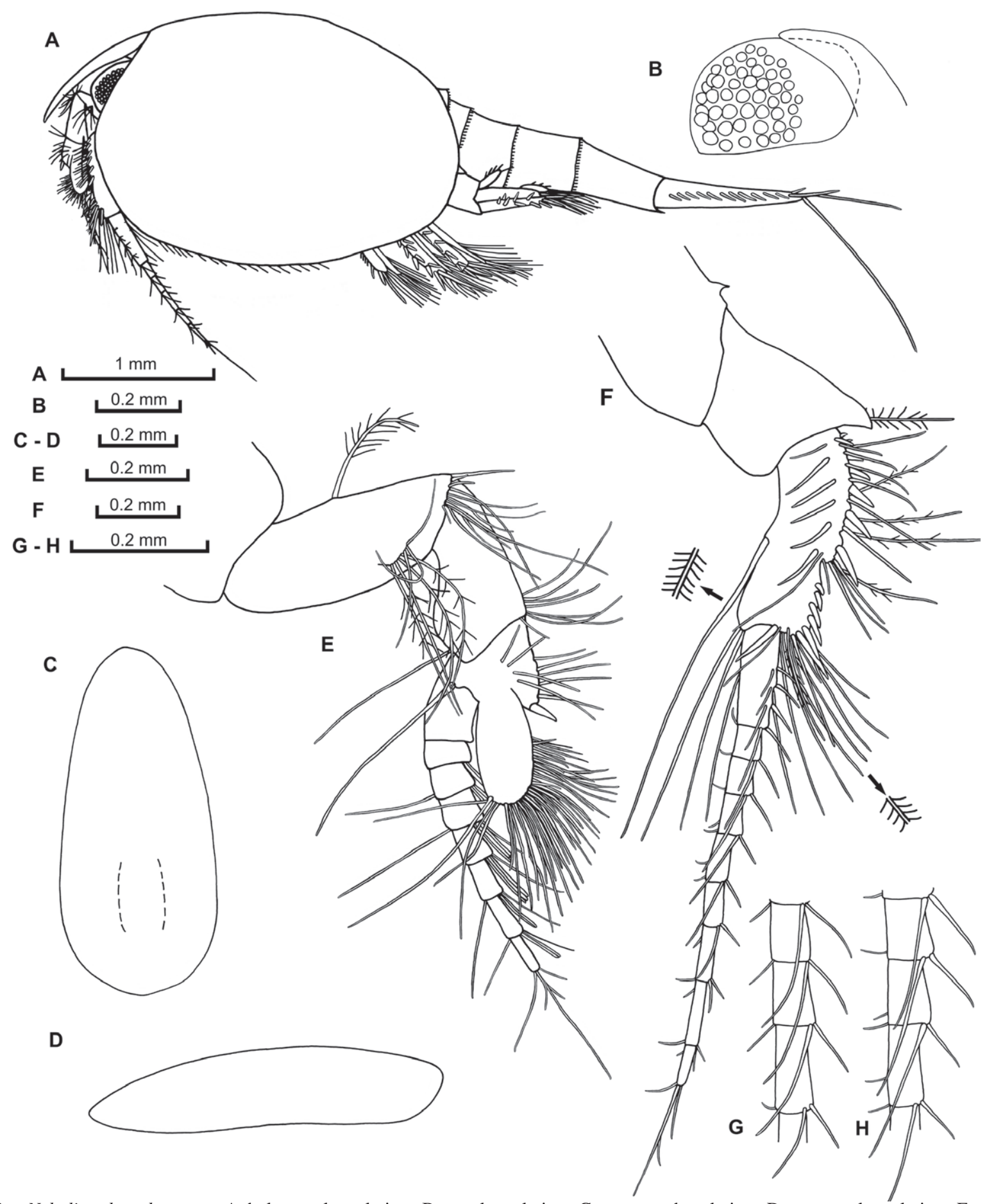

Fig. 2. - Nebalia reboredae n. sp.; A, holotype, lateral view; B, eye, lateral view; C, rostrum, dorsal view; D, rostrum, lateral view; E, antennule, lateral view; F, antenna, lateral view; G, antennal flagellum, detail, internal side; H, antennal flagellum, detail, external side.

ous female, 3 juveniles (MNCN 20.04/7998), st. SC1, 19 August 2007. 2 ovigerous females, preovigerous female, juvenile (MNCN 20.04/7999), st. SC1, 20 August 2007. 3 subadult males, juvenile (MNCN 20.04/8000), st. SC1, 24 October 2007. 2 subadult males (ZMH K-41998), st. SC1, 7 September 2007. Preovigerous female, juvenile (ZMH K-41999), st. SC1, 21 November 2007.

Diagnosis offemale. Rostrum about 2.2 times as long as wide. Antennular scale slightly more than twice as long as wide. One short distal spine on fourth antennular article. Six spine-like setae on external lateral face of third antennal article. Second maxilla endopod proximal article longer than distal article. Second maxilla exopod longer than first article of endopod. Fourth pleonite epimeron forming posterolateral pointed proc- 


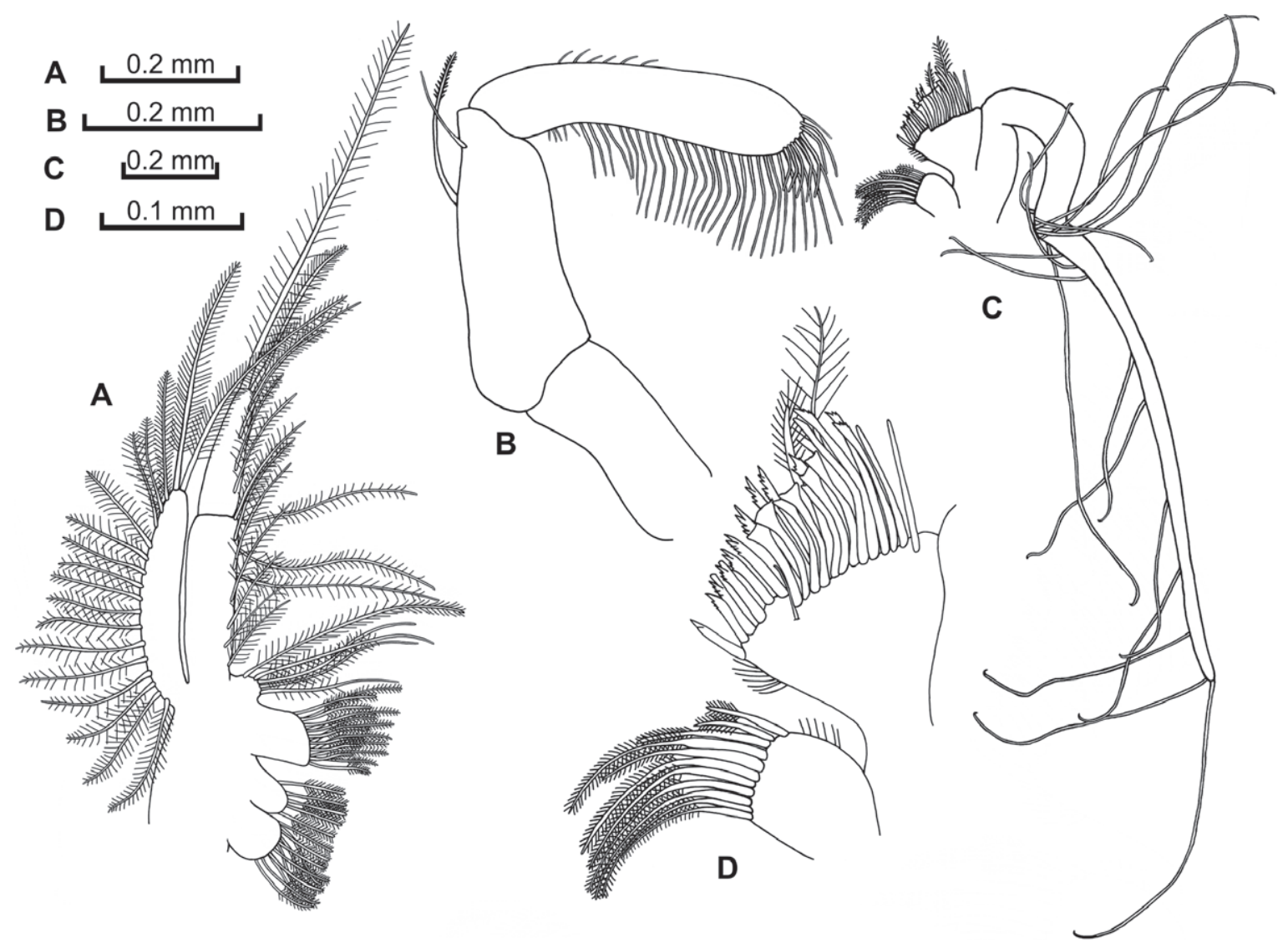

FIG. 3. - Nebalia reboredae n. sp.; A, second maxilla; B, mandibular palp (setules not illustrated); C, first maxilla; D, first maxilla, endites.

ess. Denticles along posterior dorsal borders of pleonites 5-7 distally rounded to truncated. Pleopod 4 protopod with smooth posterior border; posterolateral corner slightly pointed. Uropods as long as pleonite 7 and anal somite combined. Terminal seta of uropods about 1.4 times length of entire ramus.

Description of female. Carapace: oval, covering lateral sides of pleonite 3 and most of pleonite 4 (Fig. 2A). Average LCL $2.1 \mathrm{~mm}(\mathrm{n}=10)$; carapace about 1.4 times longer than high $(\mathrm{n}=10)$.

Rostrum: Long, extending beyond eyestalk. Average length of rostrum $0.8 \mathrm{~mm}(0.37$ times LCL; $\mathrm{n}=10$ ), about 2.2 times as long as wide (Fig. 2C); with more or less parallel margins, distally tapering to a rounded apex (Fig. 2D). Ventral keel protruding posteriorly, with medial depression where supraorbital plates fit in.

Compound eye: Oval, with ommatidial part covering about two-thirds of total length of eyestalk, dark pigmentation covering almost entire ommatidial part (Fig. 2B). Eyestalk not lobed; ventrodistal region bearing about 30 simple small setae bearing small setules along distal half (Fig. 8A), surface coarsely granulate. Supraorbital scale tapering distally, about half-length of eyestalk.

Antennule: Peduncle four-segmented (Fig. 2E). First article shorter than eyestalk. Second article widest at midpoint, with (1) plumose seta arising from anterior third, (2) cluster of three simple setae and four plumose setae arising from lateral surface, (3) subterminal cluster of about 12 short and long simple setae. Third article shorter than the second, widest distally, with cluster of about eight simple setae on superior distal margin, one long simple seta on inferior distal margin. Fourth article shorter than third, with: (1) medial row of 4-6 simple setae (Fig. 8B); (2) one thick short spine distally; (3) lateral row of 3-4 simple setae; and (4) simple seta arising from inferior distal margin, longer than antennular scale. Antennular scale oval, slightly more than twice as long as wide; anterior margin convex, with: (1) row of setae provided with coarse teeth along margin of distal half (Fig. 8C); (2) numerous simple setae of different lengths with sharper teeth than those of (1) (Fig. 8D); and (3) one long simple seta arising from inferior distal margin. Flagellum well-developed, 


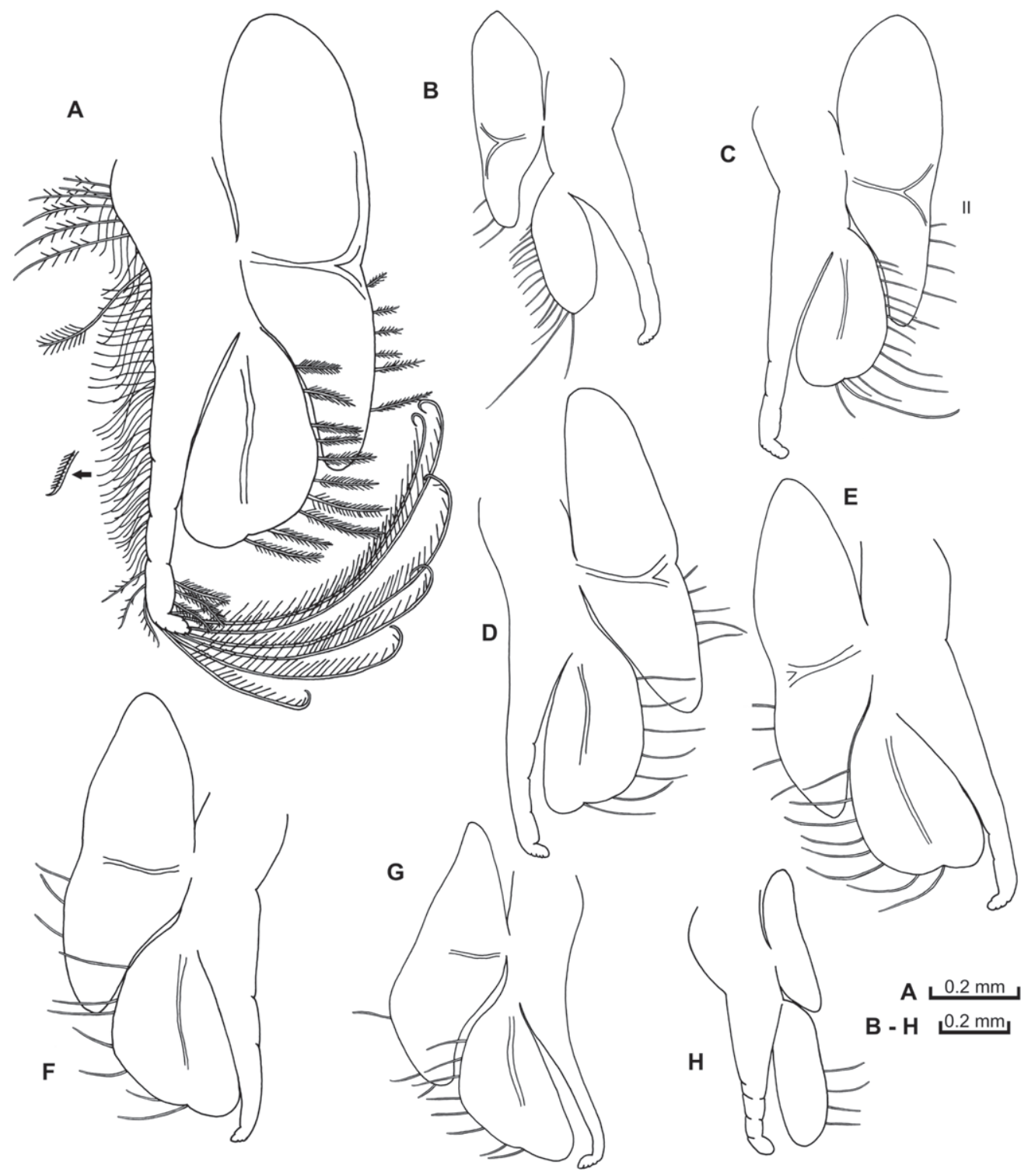

FIG. 4. - Nebalia reboredae n. sp.; A, thoracopod 3, showing setation; B, thoracopod 1; C, thoracopod 2; D, thoracopod 4; E, thoracopod 5; F, thoracopod 6; G, thoracopod 7; $\mathrm{H}$, thoracopod 8 .

with 7-8 articles, slightly shorter than the peduncle, each article with: (1) 3-5 aesthetascs as long as or longer than the article; and (2) four simple setae on anterodistal margin, one longer than the others, oriented posteriorly.

Antenna: Peduncle three-segmented (Fig. 2F). First article with anterodistal process ending in one small acute spine. Second article with distal coarsely pointed process. Third article longer than second, with several rows of setae along medial anterior margin: (1) one thin seta and six spine-like setae shorter and thicker than those of (3); (2) 8-9 longer simple setae, the two distalmost associated with four simple setae (Figs. 1A, 8E); (3) seven thick spines along proximal half, the distalmost being the longest; (4) five sparsely plumose setae; and (5) a terminal row of 7 spines, increasing distally in length, long plumose seta on posterior margin, cluster of 9 plumose setae and three shorter simple setae along distal interior margin. Flagellum well-developed, composed of 8-9 articles, each article with four terminal setae denticulated at distal end, one shorter than the others (Figs. 2G,H, 8F).

Mandible: Incisor process with sharp teeth along inner border, ending in acute process. Mandibular palp three-segmented (Fig. 3B); second article about 1.6 times as long as first; two simple setae: (1) one at mid-length on lateral face, distally plumose; and (2) shorter simple setae subterminally on anterior margin. Third article slightly longer than second, with 

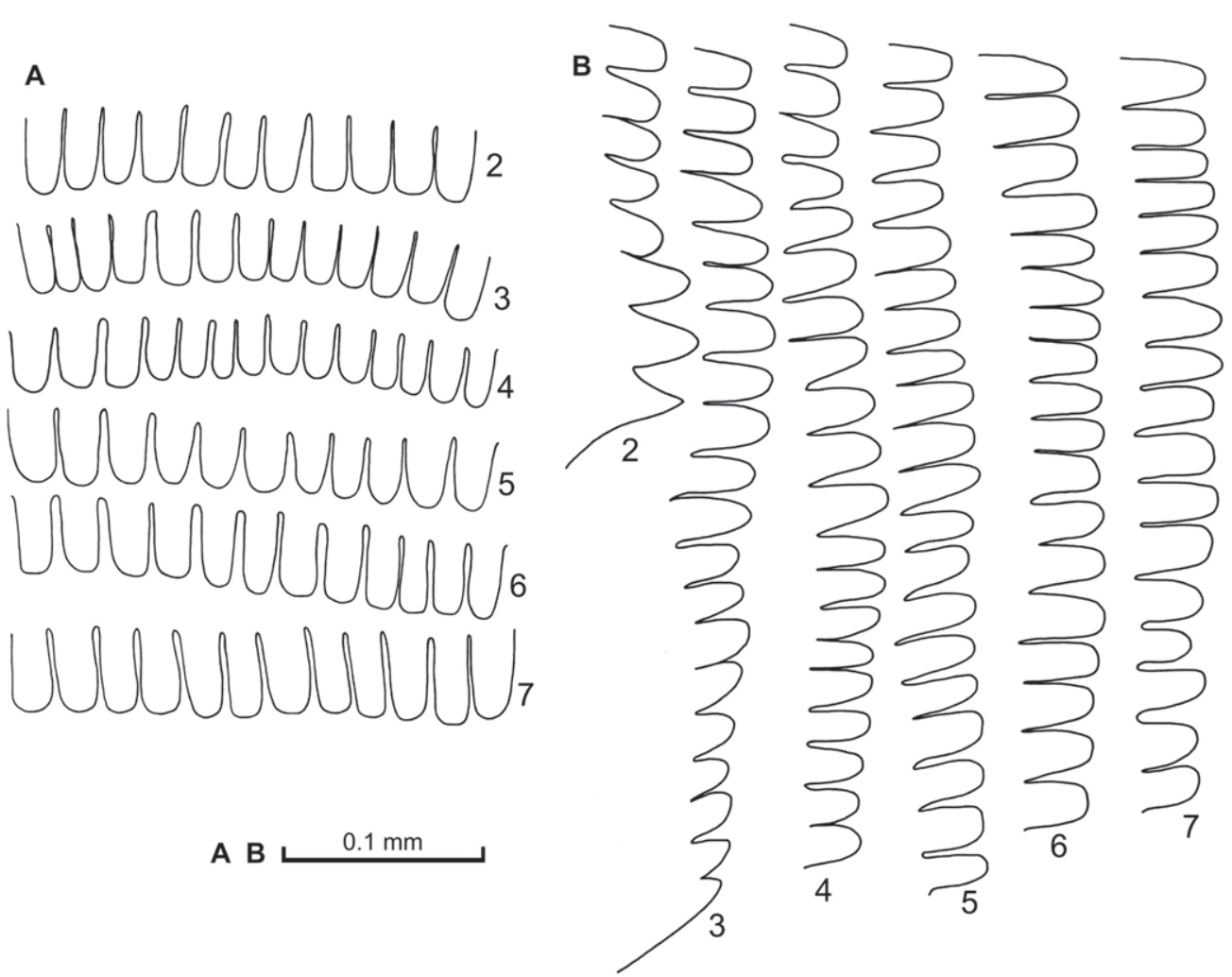

FIG. 5. - Nebalia reboredae n. sp.; A, pleonites 2-7, posterior dorsal border, denticles; B, pleonites 2-7, posterior lateral border, denticles.

margins more or less parallel; proximal half of superior margin with row of short setae; inferior margin with three rows of setae: (1) plumose setae from ending of proximal quarter extending to first half; (2) longer plumose setae than those of (1) extending along distal half (Fig. 9A); and (3) about seven curved, dentate setae along distal margin (Fig. 9B).

First maxilla: First endite (proximal) with rounded medial margin bearing simple plumose setae (Fig. 3C). Second endite (distal) larger than first (Figs. 3D, 9C); medial margin with two plumose setae and three rows of setae: (1) about 10 setae of increasing size with three large teeth along distal inferior margin accompanied by several smaller teeth (Fig. 9D); (2) about 7 spatulate setae (Fig. 9E); and (3) row of about six setae with several teeth along distal superior margin. Palp well-developed, about five times the length of protopod, with long and spaced setae along its entire length; setae with small setules along their length, apex recurved distally.

Second maxilla: Protopod with four endites bearing setae with setules, endites 1 and 3 being the largest and endite 4 being the smallest (Fig. 3A). Fourth endite with five plumose setae, the distalmost being the longest. Endopod two-segmented, longer than exopod, proximal article 1.4 times as long as distal one; lateral margin with spaced plumose setae; second article with three distal terminal setae, one of them longer than endopod. Exopod longer than the proximal article of endopod; medial margin with plumose setae, two distalmost setae as long as or slightly longer than exopod.

Thoracopods: Endopod longer than exopod (Fig. 4); with numerous setae along anterior margin. Distal article of endopod slightly enlarged, more or less directed backwards, with about 6 long plumose setae, with recurved apex. Endopod segmentation weak. Exopod with 7-15 plumose setae along posterior margin. Epipod with 3-5 plumose setae along posterior margin. Thoracopod 8 epipod smaller than those of thoracopods 1-7.

Pleonites: Pleonites 2-7 with denticles at least along posterior dorsal border (Fig. 5A); denticles with more or less parallel sides, distally truncated or rounded. Pleonite 2 bearing distally truncated to rounded denticles along posterior dorsal border. Pleonite 3 with distally truncated to rounded denticles along dorsal and lateral posterior border (Fig. 5B). Pleonite 4 with distally rounded to truncated denticles along dorsal and lateral posterior borders, postero-lateral corner slightly pointed. Pleonites 5-7 with distally rounded to truncated 


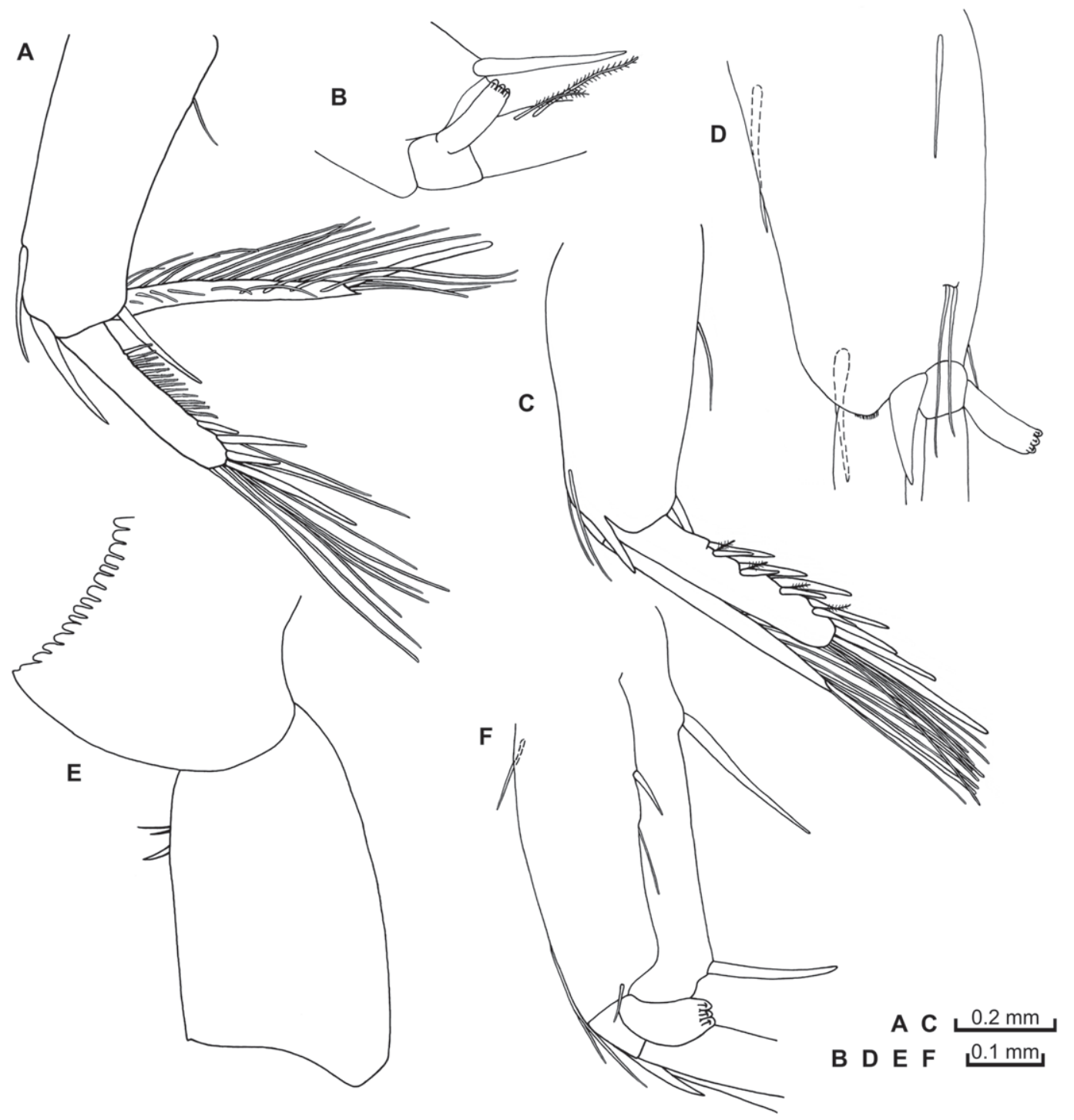

FIG. 6. - Nebalia reboredae n. sp.; A, first pleopod, lateral view (setules not illustrated); B, first pleopod, endopod, detail; C, second pleopod, lateral view (setules not illustrated); D, second pleopod, protopod, detail, ventral view; E, fourth pleopod, protopod, lateral view; F, third pleopod, protopod, posterolateral view.

denticles on dorsal and postero-lateral borders (Figs. 10A,B).

Pleopods 1-4: Pleopods 1-4 stenopodous, composed of protopod, endopod and exopod. First pleopod protopod with posterior margin even (Fig. 6A); three basal simple setae: (1) long seta arising subdistally; (2) thicker seta between the two rami; and (3) long seta near the base of exopod, reaching or surpassing proximal half of exopod; posterior margin with simple seta on proximal third. Endopod two-segmented, longer than exopod (Fig. 6B); lateral and medial margins of distal article each with about 15-17 plumose setae, distal margin with acute process at apex and long, robust terminal seta. Basal article shorter, appendix interna provided with three short recurved hooks (Fig. 10C).
Exopod about 0.7 times as long as protopod; with row of about 12-15 short serrate spines along lateral border ('spine-row'), each spine with tridentate tip, central tooth bifid (Fig. 9F); four stout smooth spines on distolateral border, the distalmost being the longest; long plumose setae along medial margin.

Pleopods 2-4 similar. Protopod with several simple setae on anterior and posterior proximal borders, cluster of two long setae subdistally, short seta next to appendix interna (Figs. 6C,D,F); acute triangular process between exopod and endopod, spine next to exopod base; posterior margin even. Endopod longer than exopod, two-segmented; proximal article short, provided with appendix interna; lateral and medial borders of distal article each with about 10 plumose 


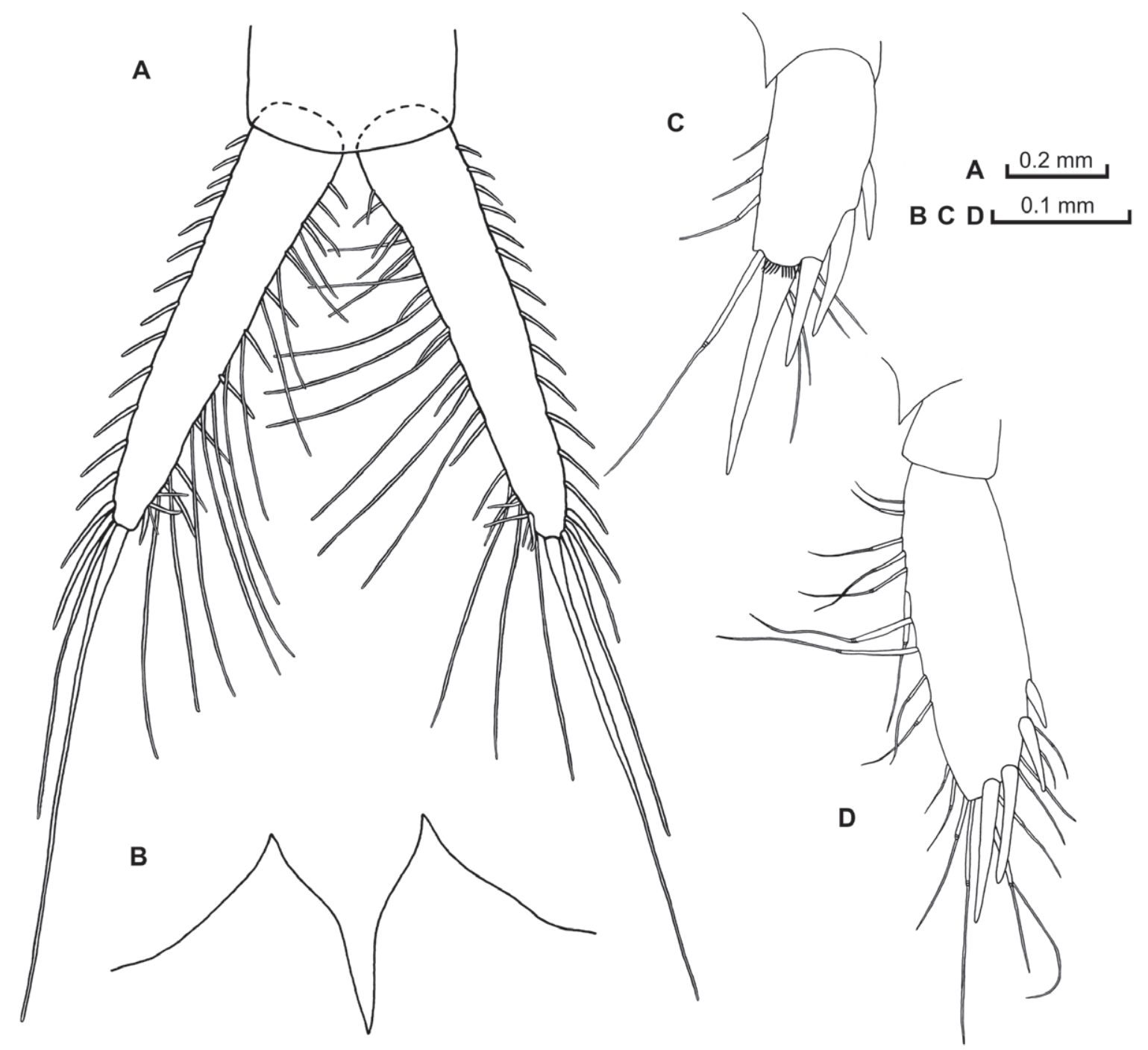

FIG. 7. - Nebalia reboredae n. sp.; A, uropods, dorsal view (setules not illustrated); B, anal plates; C, sixth pleopod; D, fifth pleopod.

setae, ending in one long spine. Exopod without a row of stout spines, instead with a row of 4-5 spine pairs, each pair consisting of one long and one shorter spine, with short plumose seta in between; medial margin with long plumose setae, three distal spines, the terminal one being the longest. Fourth pleopod protopod with two simple setae and one spine along posterior border on proximal third (Fig. 6E); posterior border even, posterior corner slightly pointed.

Pleopods 5-6: Fifth pleopod uniramous, two-segmented (Figs. 7D, 10D); distal article about 3.7 times as long as wide, with 3-4 stout conical spines along distolateral and terminal border, increasing in length distally; 22-25 simple setae along medial and distal border, setae appear jointed at midlength (Fig. 10E). Sixth pleopod uniramous, one-segmented (Fig. 7C); with 3-4 stout conical spines along distolateral and terminal border, the distalmost being the longest, as long as article, with circlet of acute teeth basally (Fig. 10F). Medial and terminal borders with 'jointed' setae similar to those of fifth pleopod. Both pleopod pairs with broad, acute triangular process between bases of rami, extending posteriorly.

Anal somite, anal plates and uropods: Anal somite (pleonite 8) short, slightly longer than pleonite 7. Anal plates with broad bases and acutely tapering distally (Fig. 7B). Uropods elongate, as long as pleonite 7 and anal somite combined. Each uropod with about 16-19 robust setae along lateral margin increasing distally in size, the terminal about 1.4 times length of uropod (Fig. 7A); about 10-12 robust setae and 12-14 plumose setae on lateral inner margin, cluster of three simple spine-like setae and two thin setae subterminally.

Colour: Fixed animals whitish or transparent with apparent dark pigment in eyes. 

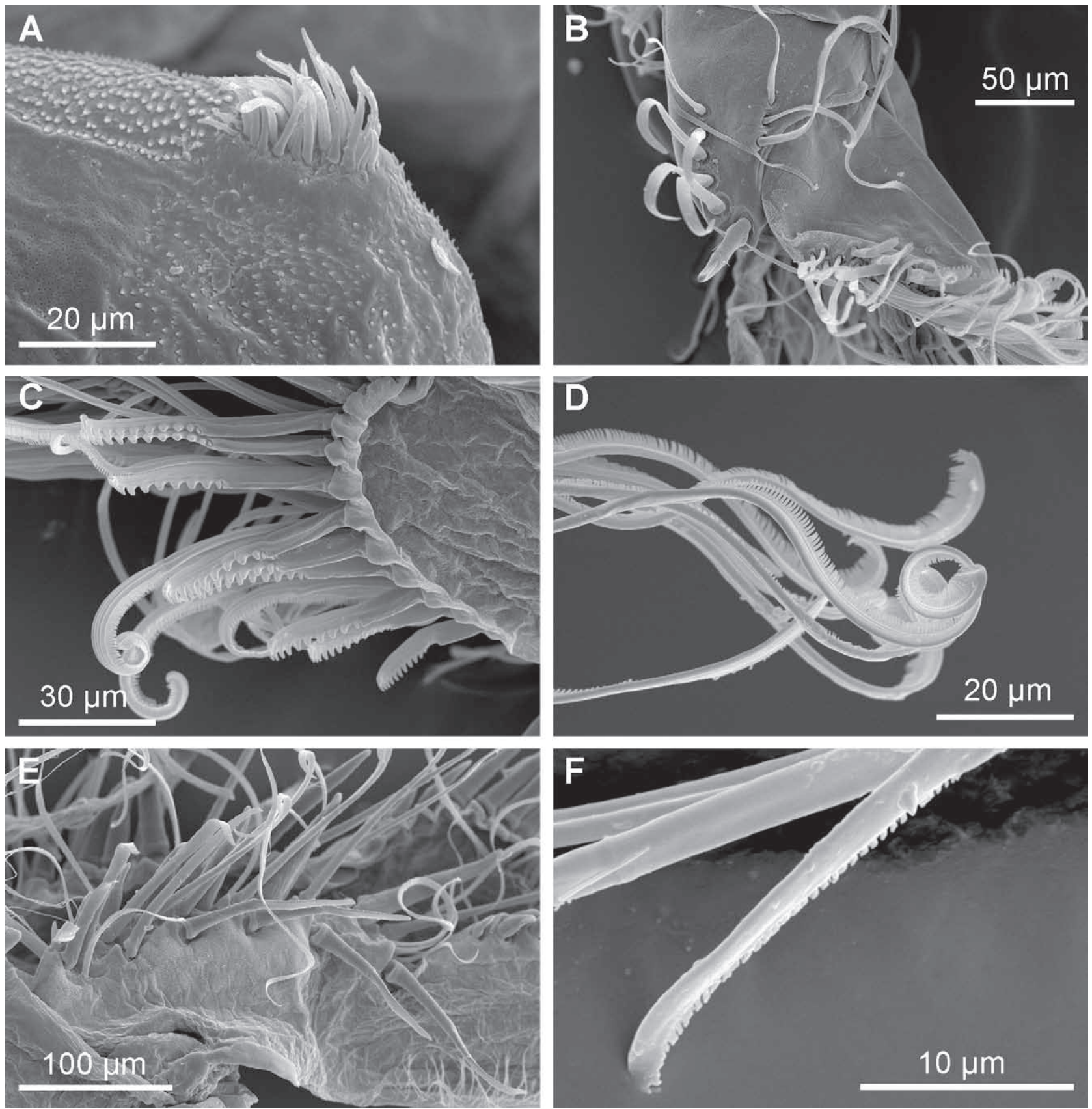

FIG. 8. - Nebalia reboredae n. sp., SEM micrographs; A, eye, ventrodistal end; B, antennule, fourth article and antennular scale, detail; C, antennular scale; short setae with coarse teeth; D, antennular scale, long setae with fine teeth; E, antenna, third article, proximal half, external side; F, antennal flagellum, distalmost article, tip of seta.

Male. Subadult males have more articles in antennal flagellum $(>12)$ than females, otherwise similar to females.

Morphological variation. Examination of all specimens in the type series shows that the number of articles of antennular flagellum increases with size (3-6 articles in juveniles of 1.4-2.4 mm TL vs 78 in adult females of 4.0-4.8 mm TL). Juveniles have fewer articles in antennal flagellum than adults (4-5 vs 8-9, respectively). Juveniles have fourth pleopod protopod with posterior corner more acute than that of adult females. The number of spines of pleopod 1 spine-row is smaller in juveniles than in adult females (5-9 vs 12-15).

Ecology. This species was collected from a site at $6.4 \mathrm{~m}$ depth whose sediment is medium sand (medi- 

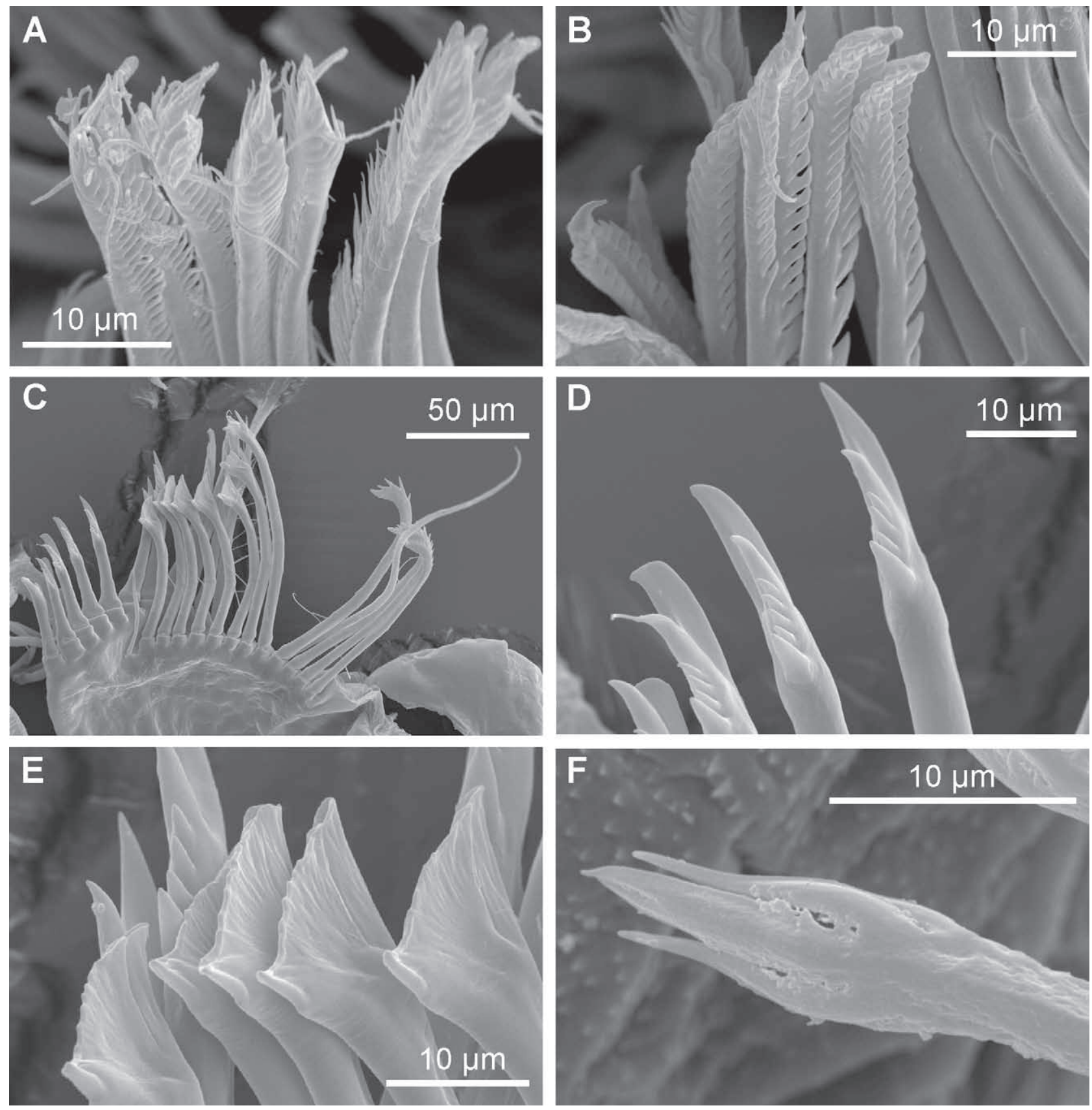

FIG. 9. - Nebalia reboredae n. sp., SEM micrographs; A, mandibular palp, third article, plumose setae; B, mandibular palp, third article, dentate setae; C, first maxilla, second endite; D, first maxilla, second endite, dentate setae, distal end; E, first maxilla, second endite, spatulate setae, distal end; F, first pleopod, spine of lateral border, distal end.

an grain size: $0.5-0.25 \mathrm{~mm}$ ). The benthic assemblage is characterised by the polychaetes Nephtys cirrosa Ehlers, 1868, Phyllodoce mucosa Örsted, 1843 and Armandia cirrosa Filippi, 1861, the bivalves Tellina donacina Linnaeus, 1758 and Thracia papyracea (Poli, 1791), the amphipods Photis longipes (della Valle, 1893), Leucothoe incisa Robertson, 1892 and Bathyporeia spp., the tanaid Apseudes latreillii (Milne-Edwards, 1828) and the pagurid, Diogenes pugilator (Roux, 1828).
Distribution. To date, Nebalia reboredae n. sp. is only known from shallow waters of the Ría de Ferrol, Galicia, Spain.

Derivatio nominis. The new species is dedicated to Dr. P. Reboreda, a Galician specialist on Isopoda, for her friendship and contributions to the knowledge of taxonomy and ecology of Crustacea from the Galician coast. 

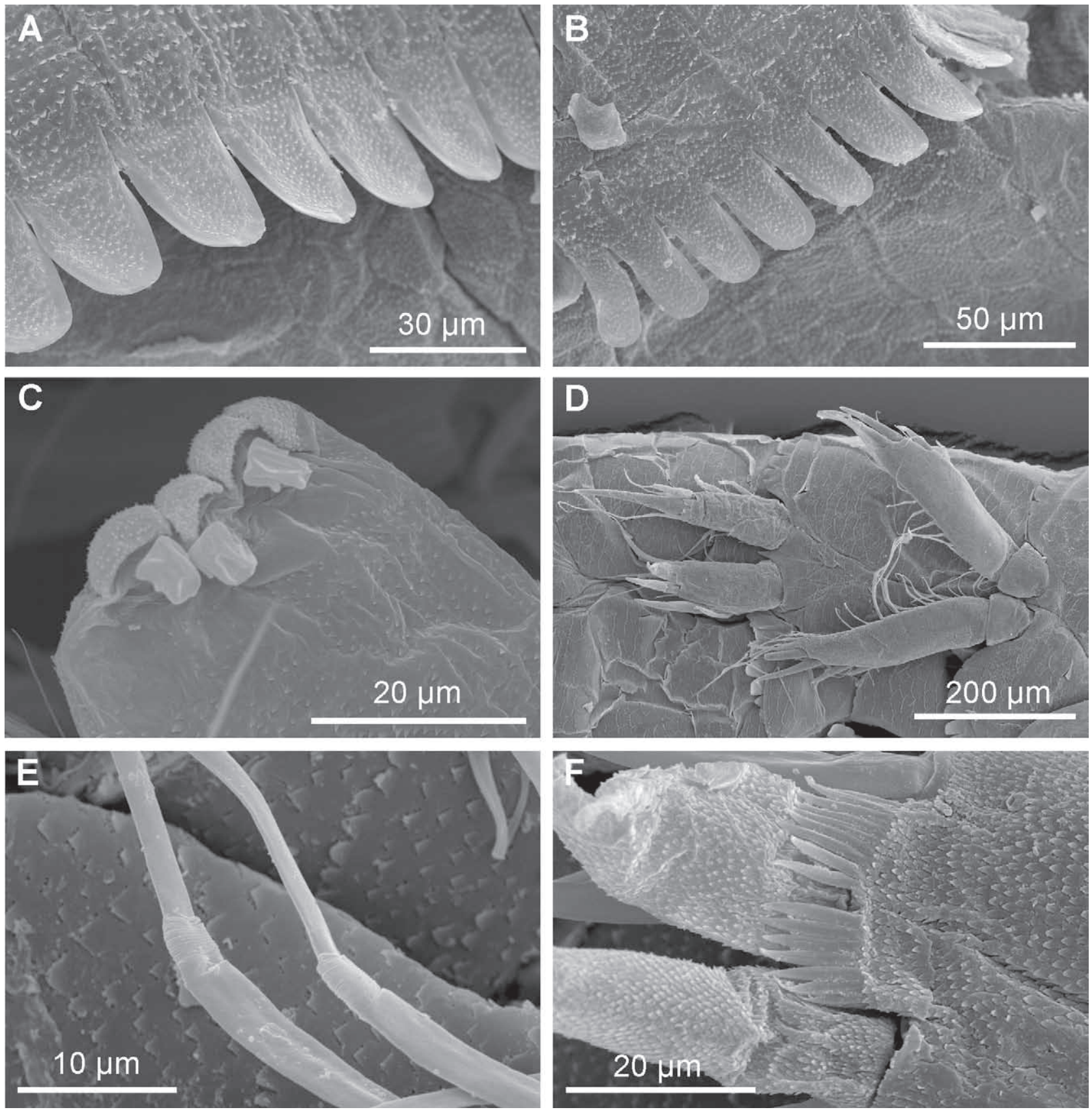

FIG. 10. - Nebalia reboredae n. sp., SEM micrographs; A, pleonite 6, posterior dorsal border, denticles; B, pleonite 7, posterior dorsal border, denticles; C, first pleopod, appendix interna, distal end; D, fifth and sixth pleopods, ventral view; E, fifth pleopod, setae of internal border, detail; F, sixth pleonite, longest distal spine, basal teeth.

Remarks. Nebalia reboredae n. sp. differs from the previously described species of Nebalia in the following unique combination of characters: the rostrum is about 2.2 times as long as wide; the antennular scale is slightly more than twice as long as wide; the fourth article of the antennule has up to one short, thick distal spine; the spines forming a row on the external lateral face of the third article of the antenna are similar to each other in length and thickness; the first article of the endopod of the second maxilla is
1.4 times as long as the second one; the exopod of the second maxilla is longer than the first article of the endopod; the posterior dorsal and lateral borders of pleonites 5-7 are provided with distally rounded to truncated denticles; the protopod of pleopod 4 has an even posterior border, with the posterolateral corner slightly pointed; the uropods are as long as pleonite 7 and the anal somite combined; and the terminal seta of each caudal ramus is about 1.4 times the length of the entire ramus. 
The following species of Nebalia also possess denticles on the posterior dorsal borders of pleonites 6-7 which are distally rounded or truncated: $N$. bipes (Fabricius, 1780), N. herbstii Leach, 1814, N. clausi Dahl, 1985, N. kensleyi Haney and Martin, 2005, N. kocatasi Moreira, Koçak and Katagan, 2007, from the northern hemisphere, and N. longicornis Thomson, 1879, N. capensis Barnard, 1914, N. ilheoensis Kensley, 1976, N. cannoni Dahl, 1990, N. falklandensis Dahl, 1990, and N. patagonica Dahl, 1990, from the southern hemisphere. Nebalia reboredae $\mathrm{n}$. sp. mainly differs from $N$. longicornis, $N$. cannoni, $N$. falklandensis and $N$. patagonica in lacking an eye dorsal papilla. In addition, $N$. bipes, $N$. herbstii, $N$. clausi, $N$. ilheoensis, $N$. kensleyi and $N$. kocatasi have a fourth article of the antennule which is provided with 3 or more thick short spines instead of one, and the antennular flagellum bears 10 or more articles in the former species while in $N$. reboredae n. sp. it bears 7-8 articles.

Nebalia capensis, from southern Africa, resembles $N$. reboredae n. sp. in its body appearance, in having a similar number of articles in the antennular flagellum and in the shape of denticles on pleonites 6-7. Nebalia reboredae n. sp. differs, however, from $N$. capensis in having uropods that are as long as pleonite 7 and the anal somite instead of being clearly shorter, an antennal flagellum that bears up to 9 articles instead of up to 11 and a posterolateral border of the fourth pleonite which is not so acutely pointed as that of $N$. capensis. Furthermore, in $N$. reboredae n. sp. the rostrum is 2.2 times as long as wide instead of being 2.5 times as long as wide as happens in $N$. capensis (Barnard, 1914). These two species also seem to differ in the number of short thick spines on the fourth article of the antennule: $N$. reboredae n. sp. has consistently one spine in all specimens examined instead of 1-2 as happens in N. capensis. Nevertheless, there are discrepancies in the descriptions of $N$. capensis regarding the number of spines and the presence of a dorsal eye papilla. Barnard (1914) originally described $N$. capensis as having one short spine and lacking a dorsal eye papilla, whereas Kensley (1976) described specimens from southern Africa assigned to the former species as those having either one spine and one dorsal papilla or two spines and lacking any dorsal papilla. Dahl (1990) considered the presence of a dorsal eye papilla as a highly valuable diagnostic character at species level. Therefore, we suspect that the specimens described by Kensley (1976) might actually belong to two different species.
Nebalia reboredae $\mathrm{n}$. $\mathrm{sp}$. also seems to differ from most of the species of the genus regarding its habitat. Many species of Nebalia have been thought to be associated with conditions of organic enrichment, close to sewage outlets or attracted to carrion (e.g. Barnard (1914), Citarella (1965), Wägele (1983), Rainer and Unsworth (1991), Olesen (1999), Macleod et al., 2007, among others). On the other hand, $N$. reboredae $\mathrm{n}$. sp. has only been found in oligotrophic sandy sediment in shallow waters, similarly to the conditions observed for other small-sized species $(<5.0 \mathrm{~mm} \mathrm{TL})$, such as $N$. daytoni Vetter, 1996, from California (1996a, 1996b, 1996d). On the other hand, in the Ría de Ferrol, $N$. reboredae n. sp. coexists with $N$. troncosoi in medium sand bottoms, but the latter is more abundant in fine sand, muddy sand and mainly in Z. marina beds (Moreira et al., 2003a).

Genus Sarsinebalia Dahl, 1985

Sarsinebalia cristoboi Moreira, Gestoso and Troncoso, 2003 (Fig. 1C)

Sarsinebalia cristoboi Moreira et al., 2003b: 191, Figs. 1-7,15A.

Material examined. $105 \mathrm{spec}$. (ovigerous female, 12 preovigerous females, 10 subadult males, 82 juveniles), st. AP2, 8 August 2006. 11 spec. ( 3 preovigerous females, 8 juveniles), st. AP2, 7 September 2006. $10 \mathrm{spec}$. (ovigerous female, 4 preovigerous females, adult male, 4 juveniles), st. NA1, 13 August 2006. 12 spec. (3 preovigerous females, 2 subadult males, 7 juveniles), st. NA9, 13 August 2006. 4 spec. (ovigerous female, 2 preovigerous females, subadult male), st. NA9, 13 August 2007. 2 juveniles, st. PE1, 13 August 2007. 6 spec. ( 2 ovigerous females, 4 preovigerous females), st. MU11, 13 August 2007.

Ecology. Coarse sediments, from gravel to medium sand, at depths of 13.5-41.1 m.

Distribution. Galicia, NW Iberian Peninsula (Moreira et al., 2003b).

Remarks. The examination of the third article of the antennal peduncle has revealed that several long setae located along the medial border and distal end are coarsely serrated along the inferior margin at the distal third (Fig. 1C). This feature was not reported in the original description by Moreira et al. (2003b), nor is it present in the other species reported here.

Sarsinebalia urgorrii Moreira, Gestoso and Troncoso, 2003 (Fig. 1F)

Sarsinebalia urgorrii Moreira et al., 2003b: 200, Figs. 8-14,15B.

Material examined. 2 spec. (preovigerous female, juvenile), st. AP1, 
7 September 2006. 3 juveniles, st. PE8, 7 September 2006. Ovigerous female, st. PE8, 19 October 2007. 2 preovigerous females, st. RP8, 13 August 2006. Juvenile, st. RP8, 13 August 2007.

Ecology. Coarse sandy sediments, from very coarse sand to medium sand, at depths of 12.7-20.0 m.

Distribution. Galicia, NW Iberian Peninsula (Moreira et al., 2003b).

\section{DISCUSSION}

To date, the Ría de Ferrol has the largest number of leptostracan species (6) ever reported from a single area and within a short bathymetric range $(<40$ $\mathrm{m})$. Another geographical area with comparable leptostracan diversity is California (Pacific coast of North America), from which four new species of Nebalia have been described in recent years (Martin et al., 1996; Vetter, 1996d; Haney and Martin, 2000, 2005). Nevertheless, as our knowledge on taxonomy, distribution and ecology of leptostracans is rather incomplete, it would not be surprising if similar or greater diversity were found in other parts of the world. Extensive sampling of different substrata both rocky and sedimentary will undoubtedly provide further support for this. For instance, Olesen (1999) and Haney and Martin (2000) pointed out the presence of several undescribed leptostracan taxa from the Tanzanian coast and Friday Harbor (Pacific coast of U.S.A.), respectively. Furthermore, Vetter (1996c, 1996d) found three species of Nebalia (one of them yet undescribed) coexisting in the same area in southern California but only two of them in the same habitat; those species also showed differences in behaviour and life history. In fact, differences in habitat preference are known to occur among species of the same genus within other benthic taxa such as polychaetes, bivalves and amphipods.

Previous work suggests that some leptostracans exhibit preferences for some type of sediment, or rather the inability to survive in other sediments. For example, Vetter (1996c) showed through experimental manipulations that $N$. daytoni and $N$. hessleri Martin, Cash-Clark and Vetter, 1996 avoided the habitat of the other species and failed to survive when transplanted to each other's habitat. Nevertheless, the processes which might explain these observations are not known (Vetter 1996c). In the Ría de Ferrol, leptostracans appeared in a number of sediments ranging from gravel to fine sand. No leptostracan was collected in muddy sediments. Furthermore, species of Nebalia were found in a wider range of sediments than those of Sarsinebalia. Nevertheless, previous data show that species of Nebalia in Galician waters tend to appear in greater numbers when seagrasses are present. Moreira et al. (2003a) reported $N$. troncosoi from medium sand to sandy mud in two inlets in southern Galicia (Ensenada de Baiona and Ensenada do Grove), although this species was more abundant in muddy sand covered by dense beds of the seagrass Zostera marina (L.). In other nearby areas in Galicia, $N$. strausi was almost exclusively found on Z. marina beds, appearing in smaller numbers on bare muddy sediments (Moreira et al., 2004). Similarly, N. kocatasi and N. strausi have been found in the eastern Mediterranean on muddy sediments mainly with the seagrass Posidonia oceanica (L.) Delile (Koçak and Katagan, 2006; Koçak et al., 2007; Moreira et al., 2007). In the Ría de Ferrol, N. troncosoi and N. kocatasi were found on fine sand with scattered mats of $Z$. marina, although they were also present in coarser sediments. In addition, $N$. strausi was only found on coarse sediments, which contrasts with the abovementioned work. However, to our knowledge, in the Ría de Ferrol dense Zostera beds such as those found in other Galician Rías are not present and therefore large numbers of $N$. strausi are not expected to occur in that ria. On the other hand, the two species of Sarsinebalia found in the Ría de Ferrol were solely collected in gravel or coarser sandy sediments, which agrees with preliminary observations by Moreira et al. (2003b). This strongly suggests that these species might prefer oligotrophic coarse sediments rather than other sediments, particularly S. cristoboi (Moreira et al., 2003b). This species might be locally abundant in the Ría de Ferrol (J. Moreira, pers. obs.) on gravel and coarse sand with shell fragments, and has not been found on sediments of finer granulometry in the Galician Rías yet. Nevertheless, sampling in the Ría de Ferrol was done with different equipment and within several sampling programmes which makes it difficult to establish reliable comparisons of species abundance among different types of sediments. Therefore, extensive quantitative data are needed in order to test the patterns suggested by our results. Manipulative experiments will also help to determine whether leptostracans from the Galician Rías show preference for any given type of substrate.

Species of Nebalia are morphologically very similar to each other and some characters are known 
to show a certain degree of variation with age and sexual condition. In fact, species from distant areas of the world show many similarities in the structure of mouthparts, appendages and body appearance (Haney and Martin, 2000). Here, we provide a key for the identification of mature females of leptostracans reported from the Iberian Peninsula as well as two further species likely to occur there, namely $N$. herbstii and $N$. clausi. The key is mostly based on features of their antenna, antennule, relative length of endopod articles of the second maxilla and dentition of pleonites. Furthermore, a figure is included showing the armature of the third article of the antenna for all species of the Ría de Ferrol (Fig. 1). Although the number of spines and setae may vary depending on age, their shape and length consistently differ among species and can be useful to identify species. In $N$. troncosoi and $N$. reboredae n. sp. spines of row 1 have a similar length and thickness while spines of row 3 are shorter and thicker in $N$. reboredae n. sp. than in N. troncosoi. On the other hand, in $N$. strausi and $N$. kocatasi the 3-4 proximal setae of row 1 are thinner and longer than the others, the latter being more robust, particularly in $N$. kocatasi. All spines are similar within row 1 for both species of Sarsinebalia but those of $S$. cristoboi are shorter and thicker than in S. urgorrii; spines of row 2 in $S$. cristoboi seem coarsely serrated along the inferior margin at the distal third instead of being smooth as appears in S. urgorrii.

\section{Key to the adult females of leptostracan species from the Iberian Peninsula shelf}

1. Rostrum with small subterminal spine; pleopod 1 exopod lacking spine-row

- Rostrum lacking subterminal spine; pleopod 1 exopod provided with spine-row

2. Eye lacking pigment and externally discernible visual elements. Sarsinebalia typhlops

- Eye provided with pigment and ommatidia .... 3

3. Supraorbital scale surpassing distal end of eye; antennal flagellum with thin long setae; pleonite 4 posterior lateral border with acute denticles ..... S. cristoboi

- Supraorbital scale not surpassing distal end of eye; antennal flagellum with short spine-like setae; pleonite 4 posterior lateral border with distally rounded to pointed denticles ............ S. urgorrii

4. Pleonites 6-7 provided with distally acute denticles
- Pleonites 6-7 provided with denticles of a different shape

5. Antennular flagellum with more than 10 articles; antennular scale more than twice as long as wide Nebalia strausi

- Antennular flagellum with up to 7 articles; antennular scale twice as long as wide

N. troncosoi

6. Antennular flagellum with more than 10 articles; antennule peduncle article 4 with three or more distal thick spines

- Antennular flagellum with less than 10 articles; antennule peduncle article 4 with one distal thick spine N. reboredae n. $\mathrm{sp}$.

7. Maxilla 2 endopod proximal article as long as distal article N. kocatasi

- Maxilla 2 endopod proximal article clearly longer than distal article.

8. Anal scale with point over centre, both margins sloping, no distinct "shoulder"; maxilla 2 exopod clearly longer than proximal article of endopod N. herbstii*

- Anal scale with point near medial margin, only medial margin sloping along entire length, lateral margin with distinct "shoulder"; maxilla 2 exopod as long as proximal article of endopod N. clausi*

*Species whose presence has not been confirmed yet in Iberian waters but are likely to occur

\section{ACKNOWLEDGEMENTS}

The authors are grateful to J. Parapar, A. Castro and C. Sueiro (Universidade da Coruña) for their technical assistance with SEM micrographs, to A. Meizoso for his help with sample collection, to J. García-Carracedo for correcting the English version of the manuscript and to E. Escobar and T. Haney for their constructive comments on earlier versions of the manuscript.

\section{REFERENCES}

Barnard, K.H. - 1914. Contributions to the crustacean fauna of South Africa. 4.- A new species of Nebalia. Ann. S. Afr. Mus., 10: 443-446.

Citarella, G. - 1965. Sur une espèce indicatrice de pollution des eaux marines. Rev. Trav. Inst. Pêches Marit., 29: 179-182.

Dahl, E. - 1985. Crustacea Leptostraca, principles of taxonomy and a revision of European shelf species. Sarsia, 70: 135-165. 
Dahl, E. - 1990. Records of Nebalia (Crustacea Leptostraca) from the Southern Hemispher-a critical review. Bull. Br. Mus. nat. Hist. (Zool.), 56: 73-91.

Escobar-Briones, E. and J.L. Villalobos-Hiriart. - 1995. Nebalia lagartensis (Leptostraca) a new species from the Yucatán Peninsula, Mexico. Crustaceana, 68: 1-11.

Haney, T.A., R.R. Hessler and J.W. Martin. - 2001. Nebalia schizophthalma, a new species of leptostracan (Malacostraca) from deep waters off the east coast of the United States. J. Crustac. Biol., 21: 192-201.

Haney, T.A. and J.W. Martin. - 2000. Nebalia gerkenae, a new species of leptostracan (Crustacea: Malacostraca: Phyllocarida) from the Bennett Slough region of Monterey Bay, California Proc. Biol. Soc. Wash., 113: 996-1014.

Haney, T.A. and J.W. Martin. - 2004. A new genus and species of leptostracan (Crustacea: Malacostraca: Phyllocarida) from Guana Island, British Virgin Islands, and a review of leptostracan genera. J. Nat. Hist., 38: 447-469.

Haney, T.A. and J.W. Martin. - 2005. Nebalia kensleyi, a new species of leptostracan (Crustacea: Phyllocarida) from Tomales Bay, California. Proc. Biol. Soc. Wash., 118: 3-20.

Junoy, J. and J.M. Viéitez. - 1989. Cartografía de los sedimentos superficiales de la Ría de Foz (Lugo). Thalassas, 7: 9-19.

Kazmi, Q.B. and N.M. Tirmizi. - 1989. A new species of Nebalia from Pakistan (Leptostraca). Crustaceana, 56: 293-298

Kensley, B. - 1976. The genus Nebalia in South and South West Africa (Crustacea, Leptostraca). Cimbebasia (A), 4: 155-162.

Koçak, C., J. Moreira and T. Katagan. - 2007. First occurrence of Nebalia straus Risso, 1827 (Phyllocarida, Leptostraca) in the Levantine Basin (eastern Mediterranean). Crustaceana, 80: 447-453.

Koçak, C. and T. Katagan. - 2006. A new record of Nebalia straus Risso, 1827 (Phyllocarida, Leptostraca) from the eastern Mediterranean. Crustaceana, 79: 319-325.

Lee, C.N. and B. Morton. - 2005. Demography of Nebalia sp. (Crustacea: Leptostraca) determined by carrion bait trapping in Lobster Bay, Cape d'Aguilar Marine Reserve, Hong Kong. Mar. Biol., 148: 149-157.

MacLeod, C.K., N.A. Moltschaniwskyj, C.M. Crawford and S.E. Forbes. - 2007. Biological recovery from organic enrichment: some systems cope better than others. Mar. Ecol. Prog. Ser., 342: 41-53.

Martin, J.W., E.W. Vetter and C.E. Cash-Clark. - 1996. Description, external morphology, and natural history observations of Nebalia hessleri, new species (Phyllocarida: Leptostraca), from Southern California, with a key to the extant families and genera of the Leptostraca. J. Crustac. Biol., 16: 347-372.

Modlin, RF. - 1996. Contributions to the ecology of Paranebalia belizensis from the waters off Central Belize, Central America. J. Crustac. Biol., 16: 529-534.

Moreira, J., E. Cacabelos and M. Domínguez. - 2003a. Nebalia troncosoi sp. nov., a new species of leptostracan (Crustacea: Phyllocarida: Leptostraca) from Galicia, Iberian Peninsula (north-east Atlantic). J. Mar. Biol. Ass. U.K. 83: 341-350.

Moreira, J., L. Gestoso and J.S. Troncoso. - 2003b. Two new species of Sarsinebalia (Crustacea, Leptostraca) from the Northeast Atlantic, with comments on the genus. Sarsia, 88: 189-209.

Moreira, J., C. Koçak and T. Katagan. - 2007. Nebalia kocatasi sp. nov., a new species of leptostracan (Crustacea, Phyllocarida) from Izmir Bay (Aegean Sea, eastern Mediterranean). J. Mar. Biol. Ass. U.K., 87: 1247-1254.

Moreira, J., P. Quintas and J.S. Troncoso. - 2004. Sobre la presencia de Nebalia strausi Risso, 1826 (Crustacea, Leptostraca) en la península Ibérica. Bol. R. Soc. Esp. Hist. Nat. (Biol.), 99: 83-92.

Olesen, J. - 1999. A new species of Nebalia (Crustacea, Leptostraca) from Unguja Island (Zanzibar), Tanzania, East Africa, with a phylogenetic analysis of leptostracan genera. J. Nat. Hist. 33: 1789-1809.

Rainer, S.F. and P. Unsworth. - 1991. Ecology and production of Nebalia sp. (Crustacea: Leptostraca) in a shallow-water seagrass community. Aust. J. Mar. Freshw. Res., 42: 53-68.

Vetter, E.W. - 1996a. Enrichment experiments and infaunal population cycles on a Southern California sand plain: response of the leptostracan Nebalia daytoni and other infauna. Mar. Ecol. Prog. Ser., 137: 83-93.

Vetter, E.W. - 1996b. Secondary production of a Southern California Nebalia (Crustacea: Leptostraca). Mar. Ecol. Prog. Ser., 137: 95-101

Vetter, E.W. - 1996c. Life-history patterns of two Southern California Nebalia species (Crustacea: Leptostraca): the failure of form to predict function. Mar. Biol., 127: 131-141.

Vetter, E.W. - 1996d. Nebalia daytoni n. sp. a leptostracan from southern California (Phyllocarida). Crustaceana, 69: 379-386.

Wägele, J.W. - 1983. Nebalia marerubri, sp. nov. aus dem Roten Meer (Crustacea: Phyllocarida: Leptostraca). J. Nat. Hist., 17: 127-138.

Walker-Smith, G.K. - 1998. A review of Nebaliella (Crustacea: Leptostraca) with the description of a new species from the continental slope of southeastern Australia. Mem. Mus. Vict., 57: $39-56$

Scient. ed.: E. Macpherson

Received April 30,2008. Accepted September 25, 2008.

Published online March 2, 2009. 